New Philadelphia 
This page intentionally left blank 


\section{New Philadelphia}

An Archaeology of Race in the Heartland

\section{Paul A. Shackel}

甲

UNIVERSITY OF CALIFORNIA PRESS

Berkeley · Los Angeles · London 
University of California Press, one of the most distinguished university presses in the United States, enriches lives around the world by advancing scholarship in the humanities, social sciences, and natural sciences. Its activities are supported by the UC Press Foundation and by philanthropic contributions from individuals and institutions. For more information, visit www.ucpress.edu.

University of California Press

Berkeley and Los Angeles, California

University of California Press, Ltd.

London, England

(C) 20 I I by The Regents of the University of California

Library of Congress Cataloging-in-Publication Data

Shackel, Paul A.

New Philadelphia : an archaeology of race in the heartland / Paul A. Shackel.

p. $\mathrm{cm}$.

Includes bibliographical references and index.

ISBN 978-0-520-26629-2 (cloth : alk. paper)

ISBN 978-0-520-26630-8 (pbk. : alk. paper)

I. New Philadelphia (III.)-History.

2. New Philadelphia (III.)-Antiquities.

3. Excavations (Archaeology)-Illinois-New

Philadelphia. 4. Community life-Illinois-New

Philadelphia-History. 5. Cultural pluralismIllinois-New Philadelphia-History. 6. Frank, Free, I777-I 854. I. Title.

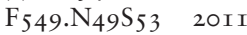

$977 \cdot 3^{\prime} 453-\mathrm{dc} 22$

2010020057

Manufactured in the United States of America

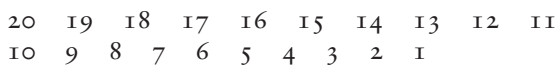

This book is printed on Cascades Enviro I00, a I0०\% post consumer waste, recycled, de-inked fiber. FSC recycled certified and processed chlorine free. It is acid free, Ecologo certified, and manufactured by BioGas energy. 
This book is dedicated to the McWorter family and the many other townspeople and community members who carry on the vision of freedom and justice inspired by the town's founders. 
This page intentionally left blank 
WE SAW A VISION

BY LIAM MAC UISTIN (I976)

In the darkness of despair we saw a vision

We lit the light of hope and it was not extinguished In the Desert of Discouragement we saw a vision

We planted the tree of valor and it blossomed

In the winter of bondage we saw a vision

We melted the snow of lethargy and the river of resurrection flowed from it

We sent our vision a-swim like a swan on the river The vision became a reality

Winter became summer

Bondage became freedom

And this we left to you as your inheritance

$\mathrm{O}$ Generations of freedom, remember us, the generations of the vision

(A poem etched on the wall in the Garden of Remembrance in Dublin) 
This page intentionally left blank 